\title{
The Possibility of Village Development: Village Regulation Formulation and Its Challenges
}

\author{
Rudy $^{1}$, Yusnani Hasyimzum ${ }^{2}$, Siti Khoiriah ${ }^{3}$, Roro Rukmi W P \\ \{rudy.1981@fh.unila.ac.id ${ }^{1}$,yusnani.hasyimzum@fh.unila.ac.id², \\ siti.khoiriah@fh.unila.ac.id ${ }^{3}$,roro.rukmi@fk.unila.ac.id ${ }^{4}$ \} \\ 1,2,3Faculty of Law, Universitas Lampung, Bandar Lampung, Indonesia \\ ${ }^{4}$ Faculty of Medical Science, Universitas Lampung, Bandar Lampung, Indonesia
}

\begin{abstract}
The new constitutionalism is giving the village new stance within Indonesia state relation. This is creating the new relation between the state and village and open wide possibility for village development. As one of the authority of the village, the authority for the formulation the village regulation maybe the key to open those possibility. Thus, The need for good regulations is very urgent in this new development since village regulation is become the foundation of village autonomy. Within the analysis above, this research test the possibility of the development through the formulation of the village regulation on two village in Lampung namely Way Empulau Ulu di West Lampung and Tanjung Setia Village in West Coast. In other side, government has enacted many regulations to govern the management of village and has made possibility to halt the development of village. This is based on the assumption that more regulation means more barrier for village formulation as Indonesia is using the model of hierarchy of law. This paper found that village regulation formulation success is depend on the political will of the people and the collaboration with legal drafter is needed to achieve the goal of village development using the formulation of village regulation.
\end{abstract}

Keywords: Village Regulation; Village Development; State Relation

\section{Background}

The village is a forerunner to the formation of society and the government in Indonesia. Long before the Indonesian nation-state was formed, social groups similar to villages or other indigenous peoples had become an important part of the archipelago. The village is a pioneer of an autonomous and fully sovereign democratic system. For a long time, the village has had a system and mechanism of government and social norms of each. Today, the village is still where we all live. At the very least, most Indonesian citizens live in villages.

Ironically, villages are often ignored in Indonesia's overall development. Since 1979, the government, through Law Number 5 of 1979 on the Village Government, has carried out structured and systematic actions to kill village autonomy. The death of village autonomy has made villages in Indonesia trapped in a sleep state for a long time, and some even died in that long sleep. It was only in 2014, the State through Law Number 6 of 2014 has set footsteps of decentralization in the village. With this law, the village has the authority to regulate and manage government affairs, the interests of the local community based on community 
initiatives, original rights, and/or traditional rights that are recognized and respected in the system of government of the Unitary Republic of Indonesia.

With this authority, the village gets very broad autonomy. This broad autonomy was then supported by the obligation to transfer village funds by the central government to each village with an amount that could be said to be fantastic. Noted, village funds from year to year continues to increase. In 2015, the village fund budget was 20 trillion IDR, in 201647 trillion IDR, and 201760 trillion IDR. Lampung Province itself was recorded receiving Village Fund disbursements of 1.9 trillion IDR in 2017. Problems that arise later, with funds that could be considered fantastic, the village and local government were shocked and looked unprepared. This can be seen from the many irregularities and failures that occur in addressing the Village Fund and village development. The results of the 2015 and 2016 Village Fund evaluations released by the ministry of finance show some irregularities that are common throughout Indonesia. The evaluation above shows that the use of village funds violates administrative regulations and even leads to corruption.

The Village Fund can be a comprehensive development weapon. The rush of village funds as a policy of decentralization of the budget to the villages to equalize development and a way to strengthen village empowerment. The goal, of course, is to empower villages so that they can create a trickle-down effect on the development and welfare of village communities. Therefore, the reformation of the ideal village development approach for rural areas is needed. Meanwhile, law and development have interrelated relationships. Amartya Sen in his phenomenal work emphasized that the development of the legal sector will have an impact on socio-economic development and even health so that legal reform and the development of legal institutions are the keys to accelerating development acceleration.

Therefore, the Village Law with its various arrangements has the potential to reduce poverty and social inequality through community empowerment mechanisms. Especially because the use of Village Funds as a backbone of village development must begin with the formation of village regulations and the preparation of village development plans so that they can be measured. Failure and inability to prepare legal documents and development planning documents are some of the causes of development failure in villages. This theoretical hypothesis was strengthened by the results of interviews with village chief stating that the lack of capacity to arrange development planning and legal documents resulted in stuttering in building empowered villages.

The success of village development as a national strategic issue then depends on the strength of accountability and the strength of empowered village communities. Therefore, community empowerment supported by legal instruments in rural areas is an important key in the success of village development. The village's need for good legislation triggers researchers to think of appropriate legislative development models for the village. At this point, the researcher then offers a model of pengayoman law as a model of village protection and empowerment. By adopting the pengayoman law model, the village will be able to optimize the eminence of each village in a legal platform that protects the community and village officials.

On the other hand, the law does not live in a vacuum space, the law intertwined with other sciences. The pengayoman law model, in this case, was born from a process of interdisciplinary interaction. At the national level, this model already applied through competency research grant application for 2016-2017. Through this research, the researcher that discusses different disciplines will try to adapt the pengayoman law model into legal development at the village level. The development of the pengayoman law in this study is interpreted as a strategy to improve the development of village regulations both in terms of the 
process and substance following the characteristics of each village. In the process aspect, what is needs attention is the systematic and synchronized planning of village regulations, transparency, and involvement of stakeholders in the formation of laws and regulations, including the model of norm formulation and its implications for justice and protection. While from the aspect of substance is to ensure that village regulations can be a tool of social engineering for the success of village development.

\section{Village Regulation as Village Development Instrument}

Development as a process of realizing prosperity, one of which is through accelerating the economy has a very close relationship with the law. De Soto in his book Mystery of Capital stated the important role of legal institutions in the economic success of a country. Holistically and specifically, legal institutions also have links with the acceleration of development and economic activities as the results of research by economists and law such as Thomas Carothers and Kenneth Dam. I Nyoman Nurjaya explained that the development of national law has placed the dominance and discrimination of state legal regulations on the people in the region, ignoring, displacing and even "killing" the values, principles, and norms of the people (customary law/folk law / indigenous law/custom law). Various laws and regulations, such as Law Number 5 of 1979 have resulted in the release of various rights, loss of village control over "property right", including the right to regulate a decent life that was originally sourced and regulated in the customary law of the communities.

This statement was reinforced by Zen Zanzibar MS, that villages which originally had broad scope of authority, financial resources and were more independent, in the era before the reformation had been experienced a degradation of position and authority, so that the dependence on higher autonomous regions appeared to be prominent and even tended to reach nadir. One of the keys to restoring the spirit of village autonomy to be empowered is through the development of a protective law in the village. According to Satjipto Rahardjo, many positive roles can be played by the law, namely a) Creation of new legal institutions that launch and encourage development; b) Securing the results obtained by work and business; c) the development of justice for development; d) granting legitimacy to changes; e) the use of law for overhaul; f) dispute resolution; g) regulation of government power. The role of law is in all stages of development, starting from planning, legislative implementation, decision making in the executive and administrative fields, drafting civil-based arrangements and dispute resolution.

The discussion on the relationship between law and development cannot be separated from legal, economic and institutional aspects. This doctrine clearly states that law and development are the overlapped area of three aspects, namely economics, law, and the character and form of institutions. The economic aspect influences the practices and policies of policy-making institutions, but these policies and practices are also adopted as part of economic theory. So, there is an overlapping area between the practice of policymaking institutions and economic theory. Through understanding the doctrine of law and development. Ideally, the law can become an instrument that provides a level of development ideas and at the same time becomes an instrument for establishing an established structure.

In the legal and development framework, the legal product in the form of laws and regulations is one of the inputs in the development planning and implementation. On the other hand, the development plan is a political process whose output is a legal product which is the 
operational basis for implementing development. Also, the agreed development plan document will be the basis for establishing political policies in the form of legal products as a legal basis for implementing the development plan. In this case, village regulation may be regarded as village development instrument.

Village Regulation (Perdes) definition based on the provisions of Law no 6/2014 concerning Villages determined that village regulation established by the Village Consultative Body (BPD) with the mutual agreement of the Village Chief. In other provisions concerning Village Government, Perdes was formed in the context of implementing village autonomy which is a further elaboration of the higher laws and regulations by taking into account local characteristics and culture.

The content of Perdes is all material contained in the context of implementing village autonomy and accommodating the specific conditions of the village. The Perdes draft can be initiated from the BPD and the Village Chief. The Perdes preparation program conducted through the village legislation program, so that it expected that there will be no overlap in the preparation of a Perdes material. There are several types of Perdes stipulated by the Village Government, which are encompassing of: (1) Village levies, (2) Community Forest Area Governance, (3) Village Conservation Plans, (4) Village Area Spatial Planning, (5) Village Revenue and Expenditure Budget (APBDes), (6) Village Apparatuses, (7) Village-Owned Enterprises (BUMDes), and other general regulations.

\section{Results and Discussion Village Regulation Formulation}

The establishment of a good Perdes must be based on the principle of establishing the following laws and regulations: (a) clarity of objectives, (b) the appropriate institutional or organ formation, (c) compatibility between types of regulation and its material content, (d) can be implemented, (e) ) usability and efficacy, (f) clarity of formulation, and (g) openness. In general, several steps need to be taken in preparing a Perdes. The description of each step can vary, but in general, the stages of preparing the Perdes are; (1) identification of problems, (2) identification of legal baselines, and how Perdes can solve problems, (3) preparation of technical studies, and (4) following procedures for preparation of Perdes. The next stage is the preparation of Perdes draft within the BPD, preparation of the Perdes draft within the Village Government, the process of obtaining BPD approval, the endorsement process, the Village Gazette, and the Perdes supervision mechanism.

The flow of the Perdes preparation process can be described as follows: (a) identification of issues and problems, (b) holding community consultations, (c) revising the Perdes draft if necessary, (d) conducting additional community consultations, (e) discussion at BPD, (f ) identification of the legal baseline and how the new Perdes can solve the problem, $(\mathrm{g})$ preparation of technical studies, (h) writing of the Perdes, and (i) stipulation of the Perdes. Perdes drafters need to make Perdes on behalf of and for the benefit of the community. The first step that must be taken is to ask questions about the types of problems faced by the community. Problems can include many things, including the degradation and deviation of resources which results in social unrest and inequality. In addition to identifying the problem, the Perdes draft must also identify the cause of the problem (the root of the problem) and the parties affected by these problems. To identify problems, several theories can be used to identify, for example, the ROCCIPI method (Rule, Opportunity, Capacity, Communications, Interest, Process, and Ideology).

In addition to ROCCIPI, two methods that are close to the nature and mechanism of its action can be used, namely the Fishbone method and the RIA (Regulatory Impact 
Assessment). The Fishbone method works by using in-depth research, everything is tested in a long discussion. Some of the things tested were related to Man (human); testing how human behavior (legal subjects) carry out or act so problems arise. Money; testing is done by identifying how the position of the budget in the implementation of activities that cause problems; Management; carried out testing and research whether the managerial patterns of both the system and subsystems can support or not the existing rules. Method; What is meant by the method here is related to the relationship between legal subjects (actors) with legal objects, how the model and relationship patterns are arranged in a method. Environment (environment); the environment is very influential on the presence of problems that occur, this environment is also related to external influences (globalization). This Fishbone method is carried out if indeed an analysis of a problem arises when the regulation will be applied.

In line with Fishbone, there is also RIA which is prioritize understanding of all the rules behind the preparation of new regulations. RIA is usually used as collateral to support development and investment. The use of RIA must be done in-depth research about why Perdes should be made after it has been answered what the risks are if the Perdes are made. If these things are answered then a Perdes will be involved in the good and bad sides if applied. Based on the various methods above, the compilers of the Perdes can choose a method that suits the conditions of their village, all calculations about that method always emphasize community participation. Furthermore, from the inventory of problems based on the approach stated above, the Perdes draft should make a priority scale regarding the problems that must be solved as soon as possible, the problems that need to be solved together, and the problems that can be postponed. Priority scaling is important because Perdes is generally limited in scale.

The legal baseline definition is the status of village regulations that are currently in force. The legal baseline identification includes an inventory of existing village regulations and a study of the ability of village officials to carry out various village regulations. Identification of legal baselines also includes an analysis of the implementation and enforcement of existing Perdes. Through this analysis, it can be seen parts of existing Perdes, which have and have not/are not yet enforced. The enactment of the new Perdes should be pursued by using new methods to change community behavior, such as through voluntary programs based on incentives, or recognition of adat rights. Also, if village officials are not transparent and are not accountable, it is difficult to expect that the enactment of the new Perdes will immediately be implemented well in the future. So the new Perdes can form an independent agency, or give authority and empower non-governmental organizations and traditional institutions, to ensure accountability in decision making.

In the preparation of the Perdes so far, it is still not equipped with academic studies. For the Perdes to be prepared to truly answer the needs of the village community and answer the problems to be arranged, the preparation of academic studies is very important. Substantially, academic studies must examine three substance problems, namely: (1) answering the question why a new Perdes is needed, (2) the scope of material content and the main components of the Perdes, and (3) the process that will be used to compile and ratify the Perdes. Academic studies do not have to contain chapters related to the proposed Perdes. The form and content of academic studies at least contain the idea of a holistic and futuristic arrangement by including various scientific aspects with references that contain urgency, conception, foundation, legal basis and principles used as well as thoughts on norms set forth in the form of articles -the article by appointing a number of alternatives presented in the form of a systematic description and can be justified legally in accordance with the politics of law outlined. 
Specifically, the technical preparation and format of academic studies for the Perdes are not yet available, but in general, the format for preparing academic studies consists of two parts, namely: the first part contains reports on the results of studies and research on the Village Regulation Draft. The second part contains the initial draft of Perdes draft which consists of proposed articles. The format of academic studies includes an introduction, scope of academic studies, and conclusions and suggestions.

Preliminary/introduction; which contains the main thoughts about the constellation of facts which are reasons for the importance of the relevant legal material without being regulated and a list of relevant Perdes and can be used as a legal basis (Background); The goals and uses to be achieved; Method and approach; and Organizing. Scope of Academic Studies; consists of general provisions containing terms/meanings used in academic studies and their respective meanings. The second content is material that contains the conceptions, approaches, and principles of regulated legal material as well as suggested normative thoughts, as far as possible by suggesting several alternatives. Conclusions and recommendations; which contains a summary of the main contents of academic studies and the scope of the material that is regulated and which relates to other village regulations and the form of regulation that is related to the material content. Suggestions contain whether all material is regulated in one form of village regulation or there is a part that is otherwise outlined in the implementing regulations or other regulations. Academic studies must be arranged carefully and cautiously. The formation of a drafting team and a consulting or steering team must be carried out. Likewise, village consultation meetings (public consultation) must continuously be held to revise the academic study draft. The first step of the village apparatus is to form a drafting team formed based on the decree of the Village Chief.

To improve the quality of Perdes products, a process or procedure for preparing Perdes is needed to be more directed and coordinated. This is due in the formation of Perdes it is necessary to prepare carefully and deeply, including knowledge of the material into the Perdes briefly but clearly with good language and easy to understand, arranged systematically without leaving procedures by Indonesian language rules in the preparation the sentence. This drafting procedure is a series of activities for the drafting of village legal products from planning to enactment.

\section{The Drafting Experience in Two Villages}

To test our model, we try to do experiment in two villages, namely Way Empulau Ulu and Tanjung Setia village. Culturally, the life of the Way Empulau Ulu community is very interesting. Lampung's local customs still live well, while the culture of the immigrants also well developed. The fact finding was obtained by the team when testing the research results. Based on history, at first the Marga Liwa originated from a traditional law community called Buay Betawang. Buay Betawang is what later gave birth to the Marga Liwa in West Lampung. Way Empulau Ulu itself, which is centered in the hamlet of Negeri Agung, is led by the Marga Liwa, whose leadership is called Pengikhan Marga Liwa. In addition, Marga Liwa itself consists of several traditional elders, consisting of:

1. Umpu Buay Betawang;

2. Umum Dugu;

3. Umpu Gajah Mencecak; and

4. Umpu Sepulau Langgar.

Marga Liwa area has restrictions ranging from West Lampung Sekuting to Ranau OKU, South Sumatra. Although currently there has been an administrative depreciation based on the Way Empulau Ulu area which is the center of the Marga Liwa government. Then, according to 
one of the traditional elders found in the Way Empulau Ulu named Suttan Syahrir, the traditional composition of Marga Liwa is still maintained today. In his statement, he also explained that the traditional arrangement is denoted by the following names that apply in stages starting from the highest position namely the title Pengikhan, Suttan, Dalom, Inner, Radin, Kinak, Kimas, and Witon.

Way Empulau Ulu is a typical traditional/adat village that submerged by the regulation of Law Number 5 Year 1979 concerning Village Government. However, Law Number 6 Year 2014 concerning Villages gives hope to villages that have historical lines of custom to reclaim that status. The interviews results with local communities led to the discovery of the fact that tradition and adat are still held so firmly, and there is a strong desire from the Way Empulau Ulu community to improve the status of their village to become an adat village. this gave the research team a big picture in assisting in the village regulation drafting that support the achievement of the status of the adat village.

Differ from the first case, in the second case with the village of Tanjung Setia which patterned as a tourism village, because of its geographical location which is directly adjacent to the beach. However, it has a heavy burden in the its development. Because as an icon of surfing heaven in the world. Tanjung Setia village cannot manage tourism tax or retribution because it is the domain of the West Pesisir district government. In fact, there are very critical environmental issues related to waste management produced by tourists. In this regard, the community and the village government of Tanjung Setia also hope to find a solution or regulation that can help in overcoming the issue. Therefore, the village regulation that would be drafted based on this matter as main issue.

\section{Conclusion}

This paper found that village regulation formulation success is depend on the political will of the people and the collaboration with legal drafter is needed to achieve the goal of village development using the formulation of village regulation.

\section{References}

[1] Carothers, Thomas (ed.). 2006. Promoting The Rule Of Law Abroad: In Search Of Knowledge. Carnegie Endowment for International Peace.

[2] Dam, Kenneth. 2006. The Law-Growth Nexus: The Rule Of Law And Economic Development. Brookings Institution Press.

[3] M.S., Zen Zanibar. 1988/ 1999. Otonomi Desa Dengan Acuan Khusus Pada Desa Di Propinsi Sumatera Selatan. Disertasi Program Doktor. Fakultas Hukum: Universitas Indonesia.

[4] Nurjaya, I Nyoman. 2007. Reorientasi Pembangunan Hukum Negara Dalam Mayarakat Multikultural ; Perspektif Antropologi Hukum. Pidato Pengukuhan Jabatan Guru Besar Dalam Bidang Ilmu Hukum: Universitas Brawijaya Malang.

[5] Rahardjo, Satjipto. 1980. Hukum dan Masyarakat. Bandung: Angkasa.

[6] Soto, Hernando De. 2010. Mystery of Capital. Transworld. 